\title{
An Econometric Study of the Impact of Monetary Policy on Foreign Direct Investment in Iraq for the Period (2004-2017)
}

Submitted 02/03/20, $1^{\text {st }}$ revision $16 / 04 / 20,2^{\text {nd }}$ revision $17 / 06 / 20$, accepted $15 / 08 / 20$

\author{
Sabah Haseeb Hasan ${ }^{1}$, Anwaar Dhiaa AbdulKareem ${ }^{2}$, Assma Abdul Ritha Daghr ${ }^{3}$
}

\begin{abstract}
:
Purpose: This paper aims to examine the impact of monetary policies on foreign direct investment (FDI) in Iraq during the period (2004-2017).

Design/Methodology/Approach: A descriptive and analytical method is used to find conclusions and recommendations that may be useful to those concerned in the field of monetary policy.
\end{abstract}

Findings: The most important results of the study reveal that there is an impact of monetary policies on foreign direct investment in Iraq during the period (2004-2017). The growth rate of money in circulation (as an indicator of monetary policy of the Iraqi central bank) has insignificant impact on FDI in Iraq. The rediscount rate and open market operation (which are instruments of monetary policy) have an insignificant effect on FDI in Iraq and there is a co-integration between the growth rate of money in circulation and FDI.

Practical Implications: The study recommends that the Iraqi central bank needs to employ more effective monetary policies that help increase the effect on FDI and its levels. Furthermore, there is a necessity to increase the effectiveness of monetary policy instruments used in the Iraqi economy, in rediscount rate and open market operations in particular.

Originality/Value: Based on the findings, we conclude that the monetary policy has affected FDI in Iraq during (2004-2017).

Keywords: Monetary policy, Foreign Direct Investment, unit root test, co-integration, error correction model, model selection.

JEL codes: M21.

Paper type: Research article.

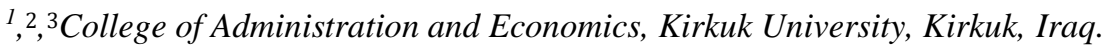

1sabahsaqi@uokirkuk.edu.iq,2anwaar71@uokirkuk.edu.iq,3abdasmaa163@gmail.com
} 


\section{Introduction}

Foreign direct investment (FDI) is one of the most important sources of funding at present as it helps to achieve economic development significantly. It provides employment opportunities and reduces unemployment in developing countries. All countries, especially developing ones, aim at attracting FDI and providing facilities and privileges that help to promote this type of investment. Through employing economic policies, States aim at maximizing FDI by providing the environment and atmosphere appropriate for such kind of investments. Monetary policy is the best economic policy that could contribute through its instruments to economic and monetary stability and provide an attractive investment environment for FDI. Research problem lies in the question, what is the impact of monetary policy on FDI in Iraq during the period 2004-2017?

In order to achieve the objectives of this study, specific hypotheses were developed as follows: (1) Monetary policy has an effect on FDI in Iraq during the period (20042017), (2) the growth rate of money in circulation in the Iraqi economy has a significant effect on FDI in Iraq during the study period, (3) rediscount rate has a significant effect on FDI in Iraq during the study period, (4) open market operations have a significant effect on FDI in Iraq during the study period, and finally (5) the legal reserve has a significant effect on FDI in Iraq during the study period.

\section{Theoretical Background}

\subsection{The Concepts of Monetary Policy}

Monetary policy refers to the means and ways whereby the State manages monetary and regulates economic activity in the community (Qady, 2013). It is also defined as the use of a range of instruments and means by which an impact on the monetary in circulation in the economy can be created (Ali, 2014). Monetary policy aims to fulfill a set of objectives, including: 1) economic growth and monetary stability; 2) organization of monetary growth; 3) achieve a satisfying level of foreign investments; 4) maintain the value of the national currency and exchange reserves (Mustafa, 2012).

Discount rate is the interest charged by the central bank on commercial banks when these banks rediscount their securities and trading in the central bank, which helps to increase their ability to grant credit. Open market operations offered by the central bank with securities either by sale or purchase to control the ability of banks in the banking sector to grant credit. Change the legal reserve requirement is the proportion kept by the central bank from deposits in the banks. The central bank changes it in accordance with the economic level (Hasheesh, 2012; Fahmy 2006).

The central bank manages the way whereby the commercial banks distribute loans and investments so as it controls the quantity of credit granted to each sector for 
serving the national economy and ensuring the optimum use of loans and investments. Among the most important instruments used to rationalize credit include direct influence, moral influence or persuasion, minimum liquidity ratio, regulation of consumer credit, instructions, guidance and information (Ahmed, 2003).

The Concept of FDI is defined as investments owned or partly owned by individuals or non-resident institutions within the State and do not own its nationality for making profits and benefits (Mandour, 2010). The International Monetary Fund defines it as the investment whereby individuals or resident institutions in a particular economy gain permanent interests in another economy with the aim of opening new markets or increase production and take advantage of the abundance of available productive resources (Al-Samara'i, 2006).

Joint investment is one of the business projects owned by and involves two or more different States. The joint investment ensures a representative of the national interests in the management of the investment project to maintain national interests. Foreign-owned investment means that investor creates a product or service activity within the host State, and the entire project is owned by a foreign investor (Fatiha, 2017).

\subsection{Previous Studies}

Souad's (2011) study, entitled "the role of financial policy in attracting FDI in Maghreb countries", aimed at identifying ways and methods used by Morocco, Algeria and Tunisia to attract FDI. The study results verified the hypothesis saying that FDI is a tool for growth and development, and it is a low-cost funding source. The study found that there are many advantages of FDI as well as disadvantages that should be avoided and eliminated. The study recommended the necessity of creating a suitable environment for FDI by the host State. The financial policy in Algeria did not prove its effectiveness in attracting FDI whereas the Tunisian one proved its usefulness in attracting FDI. Finally, there are many factors that affect FDI other than financial policy, such as the political issues, security and social levels.

The research of Allawi and Borosha (2015), entitled "The Impact of Monetary and Financial Policy on FDI Flows in Algeria: An Econometric Study for the Period (1990-2012)" investigates the effect of the monetary and financial policy on FDI inflows to Algeria during the period (1996-2012). Through the application of the vector self-regression model (VAR) on annual data, where the rebate rate, the monetary mass and the exchange rate were chosen as variables of monetary policy, public expenditures as a variable of financial policy in addition to the value of foreign investment received to Algeria used as a variable for foreign investment. The results of the study showed that there is a causal relationship in one direction between each of the public spending, the mass of money and the rate of rediscounting on the one hand, and the inflows of foreign direct investment incoming 
to Algeria on the other hand. The results also showed a positive and significant effect of monetary and fiscal policy on foreign investment.

Dayoub's (2018) study, entitled "The effect of monetary policy on foreign direct investment in Syria" attempted to investigate the impact of monetary policy on FDI in Syria. The study utilized annual time series data set over the period 1990 to 2010. Econometric techniques include testing the stationary of data by applying (ADF) test and applying Autoregressive Distributed Lag (ARDL) method of estimation. Moreover, short run and long run estimates were found. The paper confirms that monetary policy does not have an impact on FDI inflow in Syria.

Bandar and Kadhm's (2018) study, entitled "The Impact of Financial and Monetary Policies on Economic Growth-An Econometric Study of the State of the Iraqi Economy for the Period (1980-2016)" aimed to study the relative importance of fiscal and monetary policy for economic growth in Iraq and then to determine which of these policies is more powerful in promoting economic growth in Iraq. The period of study was (1980-2016), the econometric tests were used to test the stability of time series and the co-integration of the economic variables and then to use the (VAR) test to estimate the relationship between the independent variables of government spending, money supply, and exchange rate and their impact on the dependent variable represented by the Gross Domestic Product. The study revealed that the effect of fiscal and monetary policies on the Iraqi economy is positive, and the monetary policy is more powerful in promoting economic growth in Iraq.

\section{Methodology and Data}

The study aims at identifying the relationship between monetary policy and FDI in Iraq. With regard to the methodology used, the descriptive approach was used to define the concepts and terms related to the topic as well as the analytical method by which a combination of statistical and econometric methods for data analysis were employed using Eviews software to find results and recommendations that can be utilized in future studies.

The use of time series in econometric studies requires time series stationary tests, therefore a number of statistical tests were utilized like the Augmented Dicky-Fuller test (ADF) and Co-integration tests to explore the relationship between variables based on ARDL methodology. Also, the Vector Error Correction model was used to determine the type of relationship between variables in the short and long term, as well as to find some criteria for choosing the adequate model to estimate FID. All the calculations were done using Eviews 10 software (Ergün and Göksu, 2013).

\section{Empirical Results}

Through examining the data in Table 1, it is found that the growth rate of the quantity of money in circulation (X1) in Iraq during (2004-2017) has ranged 
between a minimum of about $8.74 \%$ in 2014 and a maximum of about $17.99 \%$ in 2012. The total value of Annual Growth Rate (AGR) of the quantity of money in circulation during the study period has reached $13.22 \%$. By estimating the overall time direction equation of the growth rate of the quantity of money (X1) in circulation in Iraq during the study period, as shown in Table 2, the average quantity of money in circulation was increasing by a change rate of $0.15 \%$. However, the annual growth rate of the quantity of money in circulation in Iraq was insignificant as it reached $0.90 \%$.

Based on data in Table 1, rediscount rate (X2) in Iraq during (2004-2017) has ranged between $4.75 \%$ at a minimum in 2017 and a maximum of about $12.48 \%$ in 2006 . The value of the annual average of rediscount rate during the study period has reached $7.64 \%$. By estimating the overall time direction equation of rediscount rate in Iraq during (2004-2017), as outlined in Table 2, the rediscount rate (X2) in Iraq has decreased by a change rate of about $0.60 \%$. The annual reduction rate has reached about $7.8 \%$ for rediscount rate in Iraq at significance level 0.01 .

The data listed in Table 1 demonstrate that open market operations (X3) in Iraq during (2004-2017) ranged between a minimum of about $6.48 \%$ in 2016 and a maximum of about $14.55 \%$ in 2006 . The value of the annual average of open market operations during the study period has reached approximately $10.24 \%$. By estimating the overall time direction equation of open market operations in Iraq during (2004-2017), open market operations (X3) in Iraq has decreased by a change rate of about $0.57 \%$. The annual reduction rate has reached about $5.8 \%$ for open market operations in Iraq at significance level 0.01 (Table 2).

The data in Table 1 indicates that legal reserve (X4) in Iraq during (2004-2017) has ranged from about $12 \%$ at a minimum during 2012-2017 and a maximum of about $15 \%$ during 2004-2006. The value of the annual average of the legal reserve during the study period has reached $13.36 \%$. By estimating the overall time direction equation of legal reserve in Iraq during (2004-2017), legal reserve (X4) in Iraq has decreased by a change rate of about $0.28 \%$. The annual reduction rate has reached about $2.1 \%$ for legal reserve in Iraq at significance level 0.01 (Table 2).

Through examining the data in Table 1, FDI (Y) in Iraq during (2004-2017) has ranged from about 90 million dollars at a minimum in 2004 and a maximum of about 5532.70 million dollars in 2017. The value of the annual average of FDI during the study period has reached about 2510.84 million dollars. By estimating the overall time direction equation of FDI in Iraq during (2004-2017), as shown in Table 2 , FDI (Y) in Iraq has increased by a change rate of approximately 412.75 million dollars. The annual increase rate has reached $25.3 \%$ for FDI in Iraq at significance level 0.01 . 
Table 1. Growth rate of money quantity, rediscount rate, open market operations, legal reserve and FDIin Iraq during (2004-2017).

\begin{tabular}{llllll}
\hline Years & $\begin{array}{l}\text { The growth rate of the } \\
\text { quantity of money in } \\
\text { circulation(\%) }\end{array}$ & $\begin{array}{l}\text { Rediscount } \\
\text { rate(\%) }\end{array}$ & $\begin{array}{l}\text { Open market } \\
\text { operations } \\
(\%)\end{array}$ & $\begin{array}{l}\text { Legal } \\
\text { reserve } \\
(\%)\end{array}$ & $\begin{array}{l}\text { FDI in } \\
\text { Iraq } \\
(\text { million } \\
\$)\end{array}$ \\
\hline 2004 & 11.62 & 9.68 & 11.37 & 15.00 & 90.00 \\
2005 & 13.21 & 11.47 & 13.42 & 15.00 & 515.30 \\
2006 & 12.54 & 12.48 & 14.55 & 15.00 & 383.00 \\
2007 & 11.3 & 11.23 & 13.54 & 14.00 & 971.80 \\
2008 & 10.54 & 10.54 & 12.75 & 14.00 & 1855.70 \\
2009 & 14.62 & 7.82 & 10.68 & 14.00 & 1598.30 \\
2010 & 13.97 & 6.06 & 10.75 & 14.00 & 1396.20 \\
2011 & 16.82 & 5.91 & 9.47 & 14.00 & 1882.30 \\
2012 & 17.99 & 5.87 & 8.27 & 12.00 & 3400.30 \\
2013 & 11.23 & 5.75 & 9.37 & 12.00 & 5131.20 \\
2014 & 8.74 & 5.43 & 7.85 & 12.00 & 4781.80 \\
2015 & 10.31 & 5.16 & 7.93 & 12.00 & 3261.70 \\
2016 & 15.63 & 4.86 & 6.48 & 12.00 & 4351.40 \\
2017 & 16.52 & 4.75 & 6.88 & 12.00 & 5532.70 \\
\hline Average & 13.22 & 7.64 & 10.24 & 13.36 & 2510.84 \\
\hline
\end{tabular}

Source: Central Bank of Iraq, national data publications, different issues (2004-2017).

Table 2. Statistical indicators of the evolution of the growth rate of the quantity of money in circulation, monetary policy instruments and FDI during (2004-2017).

\begin{tabular}{llllll}
\hline Variable & Model & T-Statistic & F-Statistic & $\mathrm{R}^{2}$ & AGR (\%) \\
\hline $\mathrm{X}_{1}$ & $\mathrm{X}_{1}=12.08+0.15 \mathrm{t}$ & 0.80 & 0.64 & 0.51 & 0.90 \\
\hline $\mathrm{X}_{2}$ & $\mathrm{X}_{2}=12.15-0.60 \mathrm{t}$ & $-6.87^{* *}$ & $47.20^{* *}$ & 0.80 & $-7.8^{* *}$ \\
\hline $\mathrm{X}_{3}$ & $\mathrm{X}_{3}=14.51-0.57 \mathrm{t}$ & $-7.62^{* *}$ & $58.06^{* *}$ & 0.83 & $-5.8^{* *}$ \\
\hline $\mathrm{X}_{4}$ & $\mathrm{X}_{4}=15.48-0.28 \mathrm{t}$ & $-8.66^{* *}$ & $74.96^{* *}$ & 0.86 & $-2.1^{* *}$ \\
\hline $\mathrm{Y}$ & $\mathrm{Yi}=-584.77+412.75 \mathrm{t}$ & $8.28^{* *}$ & $68.61^{* *}$ & 0.85 & $25.3^{* *}$ \\
\hline
\end{tabular}

Note: (*) Significant at level 0.05, (**) Significant at level 0.01 .

Source: Central Bank of Iraq, national data publications, different issues (2004-2017).

A number of statistical tests were utilized. Augmented Dicky-Fuller (ADF) and Cointegration tests were used to explore the relationship between variables. Also, Vector Error Correction model was used to determine the type of relationship between variables in the short and long terms, as well as to find some criteria for choosing the adequatemodel for FID.

To measure the stationarity of variables of the model, the ADF test has been used. Table (3) shows that the stationarity of the growth rate of the series of money in circulation quantity (X1) at the same level. So, this series is of the zero-degree integration. In addition, it demonstrates the instability of the series of FDI(Y) at the same level; however, stability has occurred after considering the first difference. Thus, it is of first-degree integration (Dickey and Fuller, 1979; 1981). 
Table 3. Test results of $A D F$ for the relationship between the growth rate of the money supply and FDI.

\begin{tabular}{|c|c|c|c|c|c|c|c|c|c|}
\hline \multicolumn{10}{|c|}{ Stationary Test } \\
\hline \multirow{2}{*}{ Variable } & \multicolumn{3}{|l|}{ Level } & \multicolumn{3}{|c|}{$1^{\text {st }}$ Difference } & \multicolumn{3}{|c|}{$2^{\text {nd }}$ Difference } \\
\hline & $\mathrm{ADF}$ & Sig. & Result & $\mathrm{ADF}$ & Sig. & Result & $\mathrm{ADF}$ & Sig. & Result \\
\hline $\mathrm{X}_{1}$ & -3.191 & 0.046 & Stationary & $\begin{array}{ll}--- \\
-\end{array}$ & & & & & \\
\hline $\mathrm{Y}$ & -.720 & 0.806 & $\begin{array}{l}\text { Non- } \\
\text { stationary }\end{array}$ & -4.971 & 0.003 & Stationary & & & \\
\hline
\end{tabular}

Source: Own study.

Due to that, the two series are not integrated at the same degree, the ARDL method was used for testing co-integration between them. Based on bounds test (Pesaran et al., 2001) between the growth rate of money in circulation and FDI, as shown in Table 4, there is a co-integration between both variables at significance level 0.05 . Table 5 indicates that the optimal number of lags (Narayan, 2005) is one lag for the independent variable and three lags for the dependent variable $\operatorname{ARDL}(3,1)$.

Table 4. Bound test of Co-integration for the growth rate of money quantity and FDI.

\begin{tabular}{lllll}
\hline Test statistic & Value & Significance $(\%)$ & $\mathrm{I}(0)$ & $\mathrm{I}(1)$ \\
\hline F-statistic & 4.57038 & 10 & 3.02 & 3.51 \\
\hline \multirow{3}{*}{$\mathrm{K}$} & 1 & 5 & 3.62 & 4.16 \\
& 1 & 2.5 & 4.18 & 4.79 \\
& 1 & 4.94 & 5.58 \\
\hline
\end{tabular}

Source: Own study.

Table 5. Selection of lags for the rate of money quantity and FDI.

\begin{tabular}{lllll}
\hline Variable & Coefficient & Std. Error & T-Statistic & Prob. \\
\hline $\mathrm{Y}(-1)$ & 0.827451 & 0.274126 & 3.018504 & 0.0295 \\
$\mathrm{Y}(-2)$ & -0.628431 & 0.396422 & -1.585260 & 0.1738 \\
$\mathrm{Y}(-3)$ & 0.751980 & 0.311787 & 2.411841 & 0.0607 \\
$\mathrm{X}_{1}$ & -113.1600 & 103.3965 & -1.094428 & 0.3237 \\
$\mathrm{X}_{1}(-1)$ & 190.2760 & 93.10740 & 2.043618 & 0.0964
\end{tabular}

Source: Own study.

In order to determine the value of the related parameters in the short and long term, it is required to estimate the Error Correction Model (ECM) (Pesaran, 1999; Pesaran et al., 2001). Based on Table 6, the value of the error correction coefficient is 0.049 , which is significant at level 0.01 . In other words, there is a correction from short term to long term with a velocity of 0.049 . In contrast, the long-term equation indicates that there is no correction because $\mathrm{X} 1$, it is insignificant at significance level 0.05 . 
Table 6. Test results of the error correction model (ECM) for the relationship between the growth rateof money quantity and FDI.

\begin{tabular}{lllll}
\hline Variable & Coefficient & Std. Error & T-Statistic & Prob. \\
\hline $\mathrm{D}(\mathrm{Y}(-1))$ & -0.123549 & 0.223554 & -0.552659 & 0.6043 \\
$\mathrm{D}(\mathrm{Y}(-2))$ & -0.751980 & 0.178881 & -4.203808 & 0.0085 \\
$\mathrm{D}(\mathrm{X} 1)$ & -113.1600 & 63.09984 & -1.793348 & 0.1329 \\
CointEq(-1) & -0.049000 & 0.011184 & -4.381280 & 0.0071 \\
$\mathrm{X} 1$ & 1573.784 & 5075.480 & 0.310076 & 0.7690 \\
$\mathrm{C}$ & -2226.391 & 34854.04 & -0.063878 & 0.9515 \\
\hline
\end{tabular}

Source: Own study.

\subsection{Estimating a Model for the Impact of Monetary Policy on FDI in Iraq}

To identify the impact of monetary policies on FDI in Iraq during 2004-2017, multiple regression equation was estimated among the growth rate of the quantity of money in circulation (X1), rediscount rate (X2), open market operations (X3) and legal reserves (X4) as independent variables and FDI (Y) as dependent variable (see Table 7).

Table 7. Estimating parameters and calculating statistical indicators of FDI model.

\begin{tabular}{llll|ll}
\hline $\begin{array}{l}\text { Independent } \\
\text { Variables }\end{array}$ & Parameter & Estimate & T-test & F-test & $\mathrm{R}^{2}$ \\
\hline $\mathrm{X}_{1}$ & $\mathrm{~B}_{0}$ & 193.81 & $6.46^{* *}$ & & \\
$\mathrm{X}_{2}$ & $\mathrm{~B}_{1}$ & -10.46 & -0.125 & & \\
$\mathrm{X}_{3}$ & $\mathrm{~B}_{2}$ & 7.93 & 0.33 & $18.70^{* *}$ & 0.89 \\
$\mathrm{X}_{4}$ & $\mathrm{~B}_{3}$ & -79.70 & -0.27 & & \\
\hline
\end{tabular}

Source: Own study.

Based on results shown in the Table above, the model in whole is significant as the value of F-test is significant at level 0.01. Also, the variables in the model explain that $89 \%$ of changes occur due to FDI while the remaining are attributed to other factors not included in the model employed. This proves the first hypothesis despite the insignificance of the growth rate of the quantity of money in circulation as an indicator of monetary policy of the Iraqi Central Bank during that period. Additionally, the rediscount rate and open market operations, which are among the instruments of monetary policy, are insignificant. This explains that there are other factors affecting FDI in addition to monetary policies.

Moreover, the legal reserve has a significant effect on FDI in Iraq at significance level 0.01 . There was an inverse relationship between the two variables. It is clear that as legal reserve increases by one unit, FDI decreases by 1256.97 units, which verifies the fifth research hypothesis. On the other hand, the growth rate of the quantity of money in circulation in the Iraqi economy, rediscount rate and open market operations have no significant effect on FDI in Iraq at significance level 0.05 . This shows the invalidity of the second, third and fourth hypotheses of the study. 
Also, all possible models were estimated from independent variables with the dependent variable. Criteria of the adequate model (such as AIC, SC, HQ, Prob. (FStatistic)) were calculated. Table 8 demonstrates that the value of the criteria decreases in the presence of variable $\mathrm{X} 4$. The lowest value was for the model that contains only $\mathrm{X} 4$ as the values of underlined criteria in Table 8 were the least among other values of measurement. This emphasizes the importance and impact of the legal reserve on the FDI model.

Table 8. The adequate model criteria for estimating FDI

\begin{tabular}{lllll}
\hline Model & AIC & SC & HQ & Prob.(F-Statistic) \\
\hline $\mathrm{Y} \mid \mathrm{X}_{1}$ & 18.10862 & 18.19992 & 18.10017 & 0.735297 \\
$\mathrm{Y} \mid \mathrm{X}_{2}$ & 17.08918 & 17.18048 & 17.08073 & 0.000564 \\
$\mathrm{Y} \mid \mathrm{X}_{3}$ & 16.88131 & 16.97261 & 16.87286 & 0.000156 \\
$\mathrm{Y} \mid \mathrm{X} 4$ & $\underline{15.90531}$ & $\underline{15.99660}$ & $\underline{15.89685}$ & $\underline{0.000000}$ \\
$\mathrm{Y} \mid \mathrm{X}_{1} \mathrm{X}_{2}$ & 17.15588 & 17.29282 & 17.14320 & 0.002287 \\
$\mathrm{Y} \mid \mathrm{X}_{1} \mathrm{X}_{3}$ & 16.91242 & 17.09936 & 16.89975 & 0.000599 \\
$\mathrm{Y} \mid \mathrm{X}_{1} \mathrm{X}_{4}$ & 16.04765 & 16.18459 & 16.03497 & 0.000005 \\
$\mathrm{Y}_{2} \mathrm{X}_{2} \mathrm{X}_{3}$ & 17.02410 & 17.16104 & 17.01142 & 0.001108 \\
$\mathrm{Y}_{2} \mathrm{X}_{4}$ & 16.03822 & 16.17516 & 16.02554 & 0.000005 \\
$\mathrm{Y}_{3} \mathrm{X}_{4}$ & 16.03192 & 16.16887 & 16.01925 & 0.000005 \\
$\mathrm{Y} \mid \mathrm{X}_{1} \mathrm{X}_{2} \mathrm{X}_{3} \mathrm{X}_{4}$ & 16.31572 & 16.54396 & 16.29460 & 0.000219 \\
\hline
\end{tabular}

Source: Own study.

\section{Conclusion}

Based on the findings, we conclude that the monetary policy has affected FDI in Iraq during (2004-2017). The legal reserve as an instrument of monetary policy has a significant effect on FDI in Iraq during (2004-2017). Moreover, the growth rate of money in circulation as an indicator of monetary policy of the Iraqi Central Bank has no significant effect on FDI in Iraq during (2004-2017). Both rediscount rate and open market operations, which are monetary policy instruments, have no significant effect on FDI in Iraq during (2004-2017). There is a co-integration between both the growth rate of the quantity of money in circulation and FDI during the study period.

According to the criteria for the adequate model, the model that includes the legal reserve is the best model for representing FDI. Therefore, the legal reserve must be adopted in planning and forecasting foreign direct investment in Iraq because it is one of the most important tools of monetary policy. Finally, based on the results, we recommend that the Iraqi Central Bank has to employ more effective monetary policies that help increase the impact on FDI and attract it. It is necessary to provide all the facilities and privileges in order to attract and promote FDI in Iraq. It is also necessary to increase the effectiveness of monetary policy instruments used in the Iraqi economy, particularly the rediscount rate and open market operations.

\section{References:}


Ahmed, A.Y. 2003. The Economics of Money and Banking. University House, Alexandria, Egypt.

AL-Samara'i, D.M. 2006. Foreign investment: constraints and legal guarantees. Arabic Unity Studies Centre, Beirut, Lebanon.

Ali, A.A. 2014. Money, banking and financial markets. Dar Al-Hamid for publishing and Oman,1sted.

Allawi, M.L., Borosha, K. 2015. The Impact of Monetary and Financial Policy on FDI Inflows in Algeria: An Econometric Study for the Period (1990-2012). Journal of Economic Perspectives, Issue 9, 31-51, DOI: 10.128160017466.

Bandar, R.A., Kadhim, I.A. 2018. The Impact of Financial and Monetary Policies on Economic Growth: An Econometric Study of the State of the Iraqi Economy for the Period (1980 - 2016). Journal of Monetary and Financial Studies, Central Bank of Iraq, Special Issue: Fourth Annual Conference, December 10, 1-28.

Dickey, D., Fuller, W. 1979. Distribution of the estimators for Autoregressive Time Series With a Unit Root. Journal of the American Statistical Association, 74, 427-431.

Dickey, D., Fuller, W. 1981. Likelihood Ratio Statistics for Autoregressive Time Series with a Unit Root. Econometrica, 49, 1057-1072.

Dayoub, M.M. 2018. The Impact of Monetary Policy on FDI in Syria. Tishreen University Journal for Researchand Scientific Studies -Economic and Legal Sciences Series, 40(4), 11-26.

Ergün, U., Göksu, A. 2013. Applied Econometrics with Eviews Applications. IBU Publications, Sarajevo.

Fahmy, H.K. 2006. Instruments of monetary policy used by central banks in an Islamic economy, Research No. 63. Islamic Institute for Research and Training, Jeddah, Saudi Arabia.

Fatiha, A. 2017. The role of monetary policy in attracting foreign direct investment in Algeria (2000-2015). The Creativity Journal, 7(7), 66-80.

Hasheesh, A.A. 2012. The basics of banking and monetary economy. New University House for printing and publishing, Egypt.

Mandour, E.O. 2010. The determinants of FDI under international economic changes. House of University Education, Alexandria, Egypt.

Mustafa, A.F. 2012. Monetary policies. University Youth Foundation, Cairo, Egypt.

Marzouk, A.L. 2017. Foreign Direct Investment and its Impact on Economic Performance in Iraq -Constraints and Limits. Journal of the Kufa Studies Center, 44, 231-258.

Narayan, P.K. 2005.The saving and investment nexus for China: Evidence from counter action tests. Applied Economics, 37, 1979-1990.

Pesaran, M.H., Shin, Y. 1999. An autoregressive distributed-lag Modeling Approach to Co integration analysis. In Econometrics and Economic Theory in the 20th Century: The Ragnar Frisch Centennial Symposium, (Ed.) S. Storm, Cambridge University Press, Cambridge.

Pesaran, M.H., Shin, Y., Smith, R.I. 2001. Bounds Testing Approaches to the Analysis of Level Relationships. Journal of Applied Econometrics, 16, 289-326.

Qady, A. 2013. Introduction to macroeconomic policies: assessment, analytical study. University Publications Office, 2nd ed., Algeria.

Souad, S. 2011. The role of financial policy in attracting FDI in Maghreb countries. Master thesis in international management of institutions, Doctoral School, Faculty of Economic and Management Sciences, University of Abu Bakr Belkaid, Algeria. 